J. Dairy Sci. 99:5681-5689

http://dx.doi.org/10.3168/jds.2015-10530

(C) American Dairy Science Association ${ }^{\circledR}, 2016$.

\title{
Milk production and fertility performance of Holstein, Friesian, and Jersey purebred cows and their respective crosses in seasonal-calving commercial farms
}

\author{
E. L. Coffey, ${ }^{\star} \dagger$ B. Horan, ${ }^{*}$ R. D. Evans, $\ddagger$ and D. P. Berry ${ }^{* 1}$ \\ ${ }^{*}$ Animal and Grassland Research and Innovation Centre, Teagasc Moorepark, Fermoy, Co. Cork, Ireland \\ †School of Agriculture, Food Science and Veterinary Medicine, University College Dublin, Belfield, Dublin 4, Ireland \\ flrish Cattle Breeding Federation, Bandon, Co. Cork, Ireland
}

\begin{abstract}
There is renewed interest in dairy cow crossbreeding in Ireland as a means to further augment productivity and profitability. The objective of the present study was to compare milk production and fertility performance for Holstein, Friesian, and Jersey purebred cows, and their respective crosses in 40 Irish spring-calving commercial dairy herds from the years 2008 to 2012. Data on 24,279 lactations from 11,808 cows were available. The relationship between breed proportion, as well as heterosis and recombination coefficients with performance, was quantified within a mixed model framework that also contained the fixed effects of parity; cow and contemporary group of herd-year-season of calving were both included as random effects in the mixed model. Breed proportion was associated with all milk production parameters investigated. Milk yield was greatest for Holstein $(5,217 \mathrm{~kg})$, intermediate for Friesian $(4,591 \mathrm{~kg})$, and least for Jersey $(4,230 \mathrm{~kg})$, whereas milk constituents (i.e., fat and protein concentration) were greatest for Jersey $(9.38 \%)$, intermediate for Friesian (7.91\%), and least for Holstein (7.75\%). Yield of milk solids in crossbred cows exceeded their respective parental average performance; greatest milk solids yield (i.e., fat $\mathrm{kg}+$ protein $\mathrm{kg}$ ) was observed in the Holstein $\times$ Jersey first-cross, yielding $25 \mathrm{~kg}$ more than the mid-parent mean. There was no consistent breed effect on the reproductive traits investigated. Relative to the mid-parent mean, Holstein $\times$ Jersey cows calved younger as heifers and had a shorter calving interval. Friesian $\times$ Jersey first-cross cows also had a shorter calving interval relative to their mid-parent mean. Results were consistent with findings from smaller-scale controlled experiments. Breed complementarity and heterosis attainable from crossbreeding resulted in
\end{abstract}

Received October 15, 2015.

Accepted March 15, 2016.

${ }^{1}$ Corresponding author: donagh.berry@teagasc.ie superior animal performance and, consequently, greater expected profitability in crossbred cows compared with their respective purebreds.

Key words: crossbreeding, Jersey, heterosis, Holstein, Friesian

\section{INTRODUCTION}

The process of producing more food while reducing environmental impact has become a global challenge and requires what has been referred to as "sustainable intensification" (Pretty, 1997) of global agricultural production. In this context, there is an increasing appreciation of the multifunctional characteristics and benefits of grassland farming (Jeangros and Thomet, 2004; Baumont et al., 2014; Taube et al., 2014) and previous studies have highlighted the potential for highly productive and environmentally benign grassbased milk production (Lyons et al., 2008; Peyraud et al., 2010; McCarthy et al., 2015). Although a diverse range of grazing systems are practiced internationally, many of which are economically competitive across a wide range of countries and climatic conditions (Soder and Rotz, 2001; Dillon et al., 2005; Roche et al., 2009), such systems represent only a small minority of global milk production $(\sim 10 \%$; Steinfeld and Maki-Hokkonen, 1995). Furthermore, the biological and financial efficiency of milk production in predominantly grazing systems, such as those practiced in Ireland (where grazed pasture is the primary source of nutrients), is uniquely dependent on an integrated seasonal production model. A wide variety of factors such as stocking rate (McCarthy et al., 2013), concentrate supplementation rate (Kennedy et al., 2003), and animal genetic merit (McCarthy et al., 2007; Macdonald et al., 2008) affect grazing system performance.

The selection of appropriate animals for grazing systems is uniquely complicated by the elevated importance of reproductive performance in such systems to calve compactly at the beginning of the grass-growing 
season thereby having abundant high-quality pasture in early lactation and during rebreeding (O'Mara, 2008; Washburn and Mullen, 2014). To achieve this objective, the national economic breeding index (EBI) was developed in 2001 and reflects the profit per lactation of progeny within Irish dairy systems (Berry et al., 2014; Ramsbottom et al., 2015). The EBI currently includes 18 traits and the relative emphases on milk production and reproductive performance traits are 33 and $35 \%$, respectively (Berry et al., 2014). In both controlled (Coleman et al., 2010) and commercial (Ramsbottom et al., 2012) evaluations, greater EBI has been associated with increased farm profitability compared with animals of lower EBI by virtue of increased productivity and improved reproductive performance. Previous studies both in experimental herds in Ireland (Buckley et al., 2007; Prendiville et al., 2009; Vance et al., 2012) and within larger population studies internationally (Falconer et al., 1996; Lopez-Villalobos et al., 2000a; Lopez-Villalobos and Garrick, 2002; Grainger and Goddard, 2004; Buckley et al., 2014) have demonstrated additional benefits of crossbreeding on animal performance and financial efficiency by exploiting both additive and nonadditive genetic effects (Ahlborn-Breier and Hohenboken, 1991). However, the extent of dairy crossbreeding on commercial farms in Ireland remains low, with crossbred cows accounting for just $5.2 \%$ of the Irish national dairy herd (Department of Agriculture, 2014).

The objective of the present study was to compare the biological performance of Holstein, Friesian, and Jersey purebred cows and Holstein $\times$ Jersey and Friesian $\times$ Jersey crossbred cows using a large data set of 40 commercial dairy herds practicing crossbreeding in Ireland over a 5 -yr period. Results from this large study will be useful for dairy producers to evaluate the potential of crossbreeding strategies to maximize production efficiency and profitability within grass-based systems in the future.

\section{MATERIALS AND METHODS}

Information from the Irish Cattle Breeding Federation database on 11,808 cows from 40 spring-calving dairy herds that adopted crossbreeding between Holstein, Friesian and Jersey breeds for each of the years 2008 to 2012 inclusive were available. A spring-calving dairy herd was defined as a herd in which $>80 \%$ of cows calved between January 1 and May 31 in each year of the study and represents the predominant herd type in Ireland (Berry et al., 2013). Thirty-nine of the herds contained some purebred Holstein-Friesian cows, and 5 of the herds contained some purebred Jersey cows; all herds contained Holstein-Friesian $\times$ Jersey crossbred
Table 1. Number of cows and lactation records and average parity for the different breeds and crosses used in the present study

\begin{tabular}{lrcc}
\hline Breed $^{1}$ & Cows & Lactations & Parity \\
\hline $\mathrm{HO}$ & 1,091 & 2,413 & 3.07 \\
$\mathrm{FR}$ & 16 & 53 & 2.91 \\
$\mathrm{JE}$ & 409 & 1,022 & 3.58 \\
$\mathrm{HO} \times \mathrm{FR}$ & 108 & 247 & 3.74 \\
$\mathrm{HO} \times \mathrm{JE}$ & 883 & 2,241 & 3.30 \\
$\mathrm{FR} \times \mathrm{JE}$ & 18 & 50 & 2.94 \\
$\mathrm{HO} \times \mathrm{HO} \times \mathrm{FR}$ & 3,951 & 8,716 & 3.08 \\
$\mathrm{FR} \times \mathrm{HO} \times \mathrm{FR}$ & 303 & 762 & 3.44 \\
$\mathrm{HO} \times \mathrm{HO} \times \mathrm{JE}$ & 3,757 & 8,427 & 2.96 \\
$\mathrm{JE} \times \mathrm{HO} \times \mathrm{JE}$ & 1,967 & 4,871 & 3.31 \\
$\mathrm{FR} \times \mathrm{FR} \times \mathrm{JE}$ & 52 & 138 & 2.89 \\
$\mathrm{JE} \times \mathrm{FR} \times \mathrm{JE}$ & 861 & 2,145 & 3.53 \\
$\mathrm{HO} \times \mathrm{FR} \times \mathrm{HO} \times \mathrm{FR}$ & 3,941 & 8,929 & 3.09 \\
$\mathrm{HO} \times \mathrm{JE} \times \mathrm{HO} \times \mathrm{JE}$ & 3,394 & 7,707 & 2.95 \\
$\mathrm{FR} \times \mathrm{JE} \times \mathrm{FR} \times \mathrm{JE}$ & 471 & 1,169 & 3.46 \\
\hline
\end{tabular}

${ }^{1} \mathrm{HO}=$ Holstein, $\mathrm{FR}=$ Friesian, $\mathrm{JE}=$ Jersey, $\mathrm{HO} \times \mathrm{FR}=$ HolsteinFriesian first-cross, $\mathrm{HO} \times \mathrm{JE}=$ Holstein-Jersey first-cross, $\mathrm{FR} \times \mathrm{JE}=$ Friesian-Jersey first-cross, $\mathrm{HO} \times \mathrm{HO} \times \mathrm{FR}=\mathrm{HO}$ sire $\times \mathrm{HO} \times \mathrm{FR}$ dam, $\mathrm{FR} \times \mathrm{HO} \times \mathrm{FR}=\mathrm{FR}$ sire $\times \mathrm{HO} \times \mathrm{FR}$ dam, $\mathrm{HO} \times \mathrm{HO} \times \mathrm{JE}=\mathrm{HO}$ sire $\times \mathrm{HO} \times \mathrm{JE}$ dam, JE $\times \mathrm{HO} \times \mathrm{JE}=\mathrm{JE}$ sire $\times \mathrm{HO} \times \mathrm{JE}$ dam, $\mathrm{FR} \times$ $\mathrm{FR} \times \mathrm{JE}=\mathrm{FR}$ sire $\times \mathrm{FR} \times \mathrm{JE}$ dam, $\mathrm{JE} \times \mathrm{FR} \times \mathrm{JE}=\mathrm{JE}$ sire $\times \mathrm{FR} \times \mathrm{JE}$ dam; a purebred animal was deemed to be $\geq 87.5 \%$ of the breed.

cows. The number of cows, number of lactations, and average parity of each breed and cross are in Table 1. The cows included in the study were of high total genetic merit, with an average EBI of €159. Available data included milk production lactation performance [i.e., milk yield $(\mathrm{kg})$, fat yield $(\mathrm{kg})$, protein yield $(\mathrm{kg})$, and SCC], date of birth, calving date, parity, service dates, and pregnancy diagnosis.

\section{Milk Production}

Data consisted of 305-d milk production yield (i.e., milk kg, fat kg, protein $\mathrm{kg}$, and SCC) on 24,279 lactations from 10,593 cows. Obvious data errors were removed. Milk volume yields $<2,000$ or $>12,000 \mathrm{~kg}$ were discarded. Milk fat yields or milk protein yields $<100$ and $>500 \mathrm{~kg}$ were also discarded. Somatic cell count $<1,000$ or $>999,000$ cells $/ \mathrm{mL}$ were discarded; SCC was transformed to SCS using the logarithm to the base 10 .

\section{Fertility}

Calving dates of 24,706 lactations from 10,625 cows were available. A total of 70,645 service dates were also available. Age at first calving was defined as the age at which heifers first calved; only age at first calving records between 550 and 1,250 d were retained. Calving to first service interval was defined for all cows as the number of days from calving to first service; only calving to first service records between 10 and 250 $\mathrm{d}$ were retained. The start of a herd's calving season 
for multiparous cows was defined as the first date of a 14-d period within which at least 5 multiparous cows calved. Calving in the first $42 \mathrm{~d}$ of the calving season was defined as whether or not a cow calved in the first $42 \mathrm{~d}$ of the calving season. Cows that calved in the 14 $\mathrm{d}$ before the start of the calving season were deemed to have calved in the first $42 \mathrm{~d}$ of the calving season, to account for short gestation and premature births; 3 cows calved in the 14-d period before the start of the defined calving season. Calving interval was defined as the number of days between consecutive calvings; only calving interval records between 300 and $800 \mathrm{~d}$ were retained.

The start of the herd's breeding season was defined as the first date of a 14-d period within which at least 5 cows were served. The end of the herd breeding season was defined as the last service where no subsequent service was recorded within $21 \mathrm{~d}$. Only breeding seasons between 35 and $140 \mathrm{~d}$ in length with at least 20 cows were retained. Submission rate was defined as whether or not a cow was served in the first $21 \mathrm{~d}$ of the breeding season, regardless of calving date. Calving to first service and submission rate records were discarded for herd-years where $>80 \%$ of cows were recorded to have received just one insemination; this was undertaken to remove herd-years that only recorded the last insemination, and 3 such herd-years were discarded.

Pairwise breeding-specific heterosis and recombination coefficients for each animal were calculated as

$$
1-\sum_{i=1}^{2} \text { sire }_{i} \cdot d a m_{i}
$$

and

$$
1-\sum_{i=1}^{2} \frac{\operatorname{sire}_{i}^{2}+\operatorname{dam}_{i}^{2}}{2}
$$

respectively, where sire $_{i}$ and $d a m_{i}$ are the proportion of breed $i$ in the sire and dam, respectively (VanRaden and Sanders, 2003).

\section{Statistical Analyses}

Contemporary groups of herd-year-season of calving were generated based on the algorithm described in detail by Berry et al. (2013). The algorithm grouped animals together, within herd, based on calving dates of close proximity. Contemporary group was defined separately for each trait. Only contemporary groups with 5 or more animals were retained. The numbers of records retained for analysis are in Table 2 and Table 3 for milk
Table 2. Number of records, mean and standard deviation estimates for milk production traits in the population

\begin{tabular}{lccc}
\hline Trait & $\begin{array}{c}\text { No. of } \\
\text { records }\end{array}$ & Mean & SD \\
\hline Milk yield (kg) & 23,966 & 5,017 & 1,281 \\
Fat yield (kg) & 23,863 & 226 & 53 \\
Protein yield (kg) & 23,406 & 185 & 43 \\
Fat concentration (\%) & 23,813 & 4.55 & 0.59 \\
Protein concentration (\%) & 23,389 & 3.66 & 0.25 \\
SCS (log $\log _{10}$ units) & 23,284 & 5.0284 & 0.356 \\
\hline
\end{tabular}

production and reproduction traits, respectively. Parity was defined after calving and parity structure varied per trait but was approximately $26,21,17,12$, and $24 \%$ for parities $1,2,3,4$, and $\geq 5$, respectively.

Linear mixed models and generalized estimating equations in ASREML (Gilmour et al., 2011) were used to estimate the relationship between both breed and nonadditive genetic coefficients on a series of traits. Linear mixed models were used to estimate least squares means for milk production and interval reproduction traits. Generalized estimating equations with a logit link function were used to estimate predicted probabilities for the binary traits assuming a binomial distribution of the error. Fixed effects in the model included the proportion of each breed; that is, Holstein (HO), Friesian (FR), and Jersey (JE), breed-specific heterosis (i.e., $\mathrm{HO} \times \mathrm{FR}, \mathrm{HO} \times \mathrm{JE}$, and $\mathrm{FR} \times \mathrm{JE}$ ) and breed-specific recombination (i.e., $\mathrm{HO} \times \mathrm{FR}, \mathrm{HO} \times \mathrm{JE}$, and $\mathrm{FR} \times \mathrm{JE}$ ) all fitted as continuous effects; parity (1, $2,3,4, \geq 5$ ) was included as a class effect. Both cow and contemporary group were included as random effects.

\section{RESULTS}

\section{Milk Production}

Mean milk yield, fat yield, protein yield, fat percentage, protein percentage, and geometric mean SCC for the population was $5,017 \mathrm{~kg}, 226 \mathrm{~kg}, 185 \mathrm{~kg}, 4.55 \%$, $3.66 \%$, and 133,397 cells $/ \mathrm{mL}$, respectively (Table 2). Milk volume yield was greatest for purebred Holstein cows, producing 12 and $19 \%$ more milk than their

Table 3. Number of records, mean and standard deviation estimates for reproduction traits across the population

\begin{tabular}{lrrr}
\hline Trait & $\begin{array}{r}\text { No. of } \\
\text { records }\end{array}$ & Mean & SD \\
\hline Age at first calving (d) & 4,249 & 736 & 50 \\
Submission rate (\%) & 17,261 & 74 & 44 \\
Calving to first service (d) & 10,909 & 75 & 23 \\
Calved within 42 d of calving season (\%) & 14,133 & 66 & 47 \\
Calving interval (d) & 18,244 & 379 & 58 \\
\hline
\end{tabular}


purebred Friesian and Jersey contemporaries, respectively (Table 4). Similarly, milk solids yield (i.e., fat $\mathrm{kg}+$ protein $\mathrm{kg}$ ) was greatest for purebred Holstein cows; milk solids yield of the Holstein cows was $9 \mathrm{~kg}$ (2\%) greater than that of purebred Jersey cows and 43 $\mathrm{kg}(11 \%)$ greater than that of purebred Friesian cows (Table 4). Milk constituents (i.e., fat percentage and protein percentage) were 17.0 and $15.6 \%$ greater for purebred Jersey cows relative to their purebred Holstein and Friesian contemporaries, respectively (Table 4). Somatic cell count was least for purebred Friesian cows, $14.5 \%(13,960$ cells $/ \mathrm{mL})$ and $8 \%$ (7,600 cells/ $\mathrm{mL}$ ) lower than that of purebred Holstein and purebred Jersey cows, respectively (Table 4).

Holstein $\times$ Jersey first-cross $\left(\mathrm{F}_{1}\right)$ cows produced more $(P<0.001)$ milk compared with the parental breed average (Table 4), equating to $264 \mathrm{~kg}$ (i.e., $5.6 \%$ heterosis) greater milk volume, $15 \mathrm{~kg}$ (i.e., $6.5 \%$ heterosis) greater milk fat yield, and $11 \mathrm{~kg}$ (i.e., $6.3 \%$ heterosis) greater milk protein yield. Somatic cell count was $8.6 \%$ $(9,800$ cells $/ \mathrm{mL})$ greater $(P<0.001)$ for Friesian $\times$ Jersey $\mathrm{F}_{1}$ cows compared with the parental breed average (Table 4). Positive recombination effects were observed in multi-generational Holstein $\times$ Friesian cows, resulting in greater milk yield $(P<0.001)$, milk solids yield $(P<0.001)$, protein concentration $(P<0.05)$, and SCC $(P<0.05)$. Recombination effects for the other breed crosses were not different from zero except for the positive regression coefficient on fat concentration in Friesian $\times$ Jersey crosses (Table 4 ).

\section{Reproductive Performance}

Mean reproductive performance of the data set is in Table 2. There was no consistent breed effect on the different reproductive traits investigated. Purebred Friesian heifers calved 14 and $32 \mathrm{~d}$ younger $(P<0.001)$ than purebred Holstein and Jersey heifers, respectively (Table 5). The number of days from calving to first service was least for purebred Friesian cows, intermediate for purebred Jersey cows, and greatest for purebred Holstein cows (Table 5). Calving interval was shortest for purebred Friesian cows $(376 \mathrm{~d})$, intermediate for purebred Holstein cows (382 d), and longest for purebred Jersey cows (387 d) (Table 5). The proportion of cows served in the first $21 \mathrm{~d}$ of the breeding season was greatest for purebred Friesian cows, 6 and 14\% greater than that of purebred Jersey and purebred Friesian cows, respectively (Table 5). The proportion of multiparous cows that calved in the first $42 \mathrm{~d}$ of the calving season was 13 and $16 \%$ greater for purebred Jersey cows compared with purebred Holstein and purebred Friesian cows, respectively (Table 5).

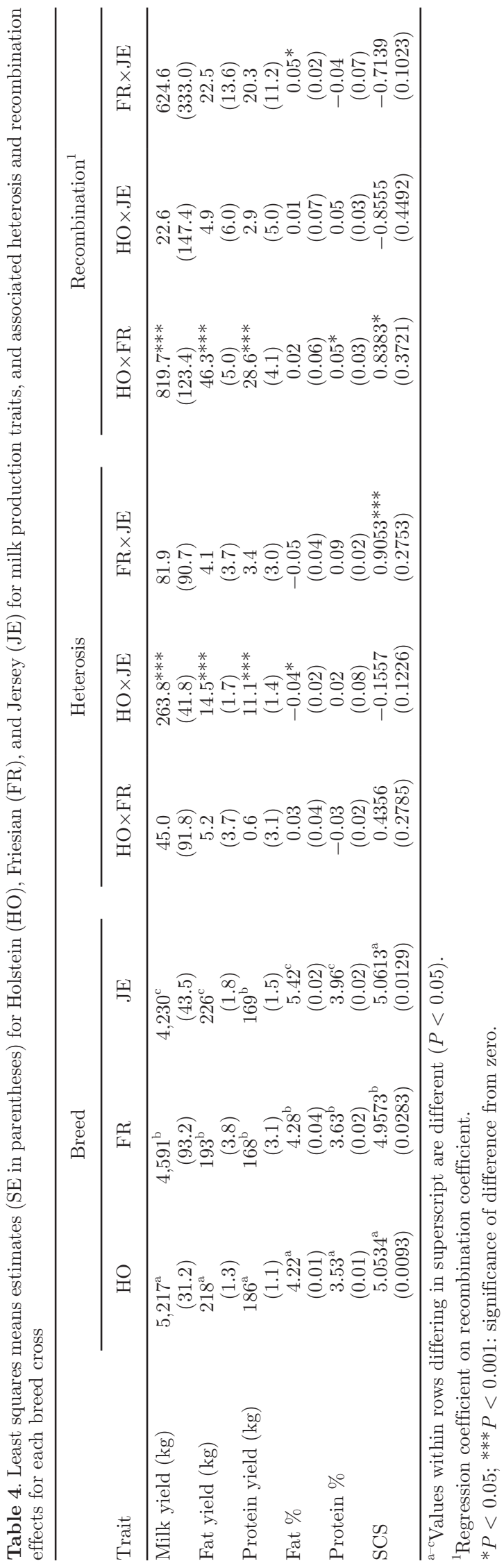


Holstein $\times$ Jersey $\mathrm{F}_{1}$ cows calved $12 \mathrm{~d}$ younger $(P<$ $0.001)$ as heifers compared with the parental breed average (Table 5), corresponding to a $1.6 \%$ heterosis effect. Holstein $\times$ Jersey and Friesian $\times$ Jersey $\mathrm{F}_{1}$ cows had an 8-d shorter (i.e., $2 \%$ heterosis; $P<0.001$ ) and a $9-\mathrm{d}$ shorter (i.e., $2.4 \%$ heterosis; $P<0.05$ ) calving interval compared with the average of their respective parental breeds (Table 5). Holstein $\times$ Jersey backcrosses had a shorter $(P<0.001)$ calving interval compared with $\mathrm{HO} \times \mathrm{JE}$ first-cross cows due to favorable recombination effects.

\section{DISCUSSION}

Selection and crossbreeding in dairy cattle have almost always been studied separately and, with the exception of New Zealand, crossbreeding of dairy cattle has received limited acceptance worldwide (Buckley et al., 2014). Recent advances in genomic selection have accelerated the rate of genetic improvement in some cattle breeds (Spelman et al., 2013). Although beneficial aspects of crossbreeding are widely documented in the literature (Buckley et al., 2014), few studies have quantified the additional benefits of crossbreeding within commercial grass-based production systems, which are already intensively selected for grass-based production characteristics (Dillon et al., 2006). Hence, the objective of the current study was to compare the milk production and reproductive performance of Holstein, Friesian, and Jersey purebred cows with their respective crosses in commercial seasonal-calving, grass-based dairy herds.

\section{Additive and Nonadditive Associations with Performance}

Heterosis is defined as the increased performance of crossbred animals compared with the average of both purebred parental breeds (Sørensen et al., 2008) and is attributable to both inter- and intra-loci allelic interactions (Lopez-Villalobos et al., 2000c). Heterosis tends to be greater for crosses between more genetically diverse breeds (Cassell, 2007). Heterosis for production traits in dairy cows typically ranges from 0 to $10 \%$, whereas heterosis for fertility traits in dairy cows typically ranges from 5 to 25\% (Swan and Kinghorn, 1992; Buckley et al., 2014). The greatest level of heterosis in the present study was observed for the Holstein-Jersey $\mathrm{F}_{1}$ cow, which was not unexpected because the 2 breeds were the most genetically diverse (Sørensen et al., 2008). Heterosis in the present study was least for the Holstein-Friesian $\mathrm{F}_{1}, 2$ breeds that are genetically very similar (Sørensen et al., 2008). 
The heterosis estimates of $5.6 \%$ for milk yield and $6.4 \%$ for milk solids observed in Holstein-Jersey $\mathrm{F}_{1}$ cows in the present study is slightly larger than the estimates of 3.7 and $5.8 \%$ for milk yield and milk solids yield, respectively, in Holstein-Friesian $\times$ Jersey $F_{1}$ reported by Prendiville et al. (2011) in a smaller controlled study in Ireland.

Reproductive efficiency is fundamental to the profitability of seasonal-calving production systems and is underpinned by the ability of cows to resume cyclicity early postcalving, express estrus, conceive, and both establish and maintain pregnancy (Berry et al., 2014). Crossbreeding has been proposed as a method to rapidly reverse the decline in reproductive performance that occurred due to "holsteinization" (Buckley et al., 2014). Heterosis effects for reproductive performance in the present study were, however, lesser than heterosis estimates previously documented (Sørensen et al., 2008; Buckley et al., 2014). All crossbred cows in the present study had a shorter calving interval relative to the average of the parental breeds corresponding to 1.5, 2, and $2.4 \%$ heterosis for Holstein $\times$ Friesian, Holstein $\times$ Jersey, and Friesian $\times$ Jersey cows, respectively. The shorter calving interval observed for the Holstein $x$ Jersey in the present study is consistent with previous research (Penasa et al., 2010) and is advantageous in seasonal milk production systems. Previous studies have also demonstrated superior reproductive performance in crossbred cows relative to parental purebreds, including a $22 \%$ greater in-calf rate to first service, a $19 \%$ greater in-calf rate after 6 wk of breeding, and an $8 \%$ greater in-calf rate after 13 wk of breeding (Prendiville et al., 2011; Vance et al., 2013).

Although first-cross cows generally perform favorably because of heterosis, performance in subsequent generations may be reduced due to the effects of recombination (Dechow et al., 2007). Recombination loss is defined as the disintegration of epistatic effects to form nonparent inter-loci combinations of alleles in crossbred animals (Cassady et al., 2002). Precise estimation of recombination effects, however, requires large numbers of second- and greater-generation crosses (Dechow et al., 2007) and the lack of significant recombination effects on milk production and fertility traits in Jersey backcross cows in the present study may be an artifact of the fewer multi-generational Jersey crossbred lactation records available (Table 1). In the present study, large but favorable recombination effects of $819.7 \mathrm{~kg}$ of milk and $74.9 \mathrm{~kg}$ of milk solids were detected in Holstein $\times$ Friesian backcrosses; however, the estimates were associated with large standard errors. Literature estimates of recombination effects for milk yield traits in dairy cattle are nonetheless variable but usually unfavorable, opposite to that observed in the present study. The previously reported recombination effects for milk yield have been reported to be between $-232 \mathrm{~kg}$ (Brotherstone and Hill, 1994) and $-135 \mathrm{~kg}$ (Akbas et al., 1993) in Holstein $\times$ Friesian crossbreds. Wall et al. (2005) also documented unfavorable recombination effects on test-day milk yield in Holstein $\times$ Friesian dairy cows, which actually exceeded the favorable heterosis effects in first-cross Holstein $\times$ Friesian cows from the same study population. In a meta-analysis of crossbred dairy cows, Lopez-Villalobos (1998) reported that recombination in multi-generational Friesian crossbreds can account for up to $80 \%$ of the heterosis effects for milk yield traits. Estimates of recombination for fertility traits in the present study were small but generally not different from zero. A favorable recombination effect was detected for calving interval in Holstein $\times$ Jersey backcross cows in the present study, consistent with that documented by Wall et al. (2005) in UK HolsteinFriesian dairy cows, although the latter estimates were not different from zero. Similarly, Dechow et al. (2007) reported a favorable, although not different from zero, recombination effect on days open, a trait similar to calving interval; recombination effects of HolsteinMontbéliarde and Holstein-Normande crosses (Dezetter et al., 2015) on calving to first service interval were $+0.3 \mathrm{~d}$ and $-4 \mathrm{~d}$, respectively, but were associated with large standard errors, rendering them not different from zero. Thus, the effect of recombination appears, in most studies (except the present study), to have unfavorable consequences for milk production but possibly weak favorable effects on reproductive performance. This is not unexpected because recombination is expected to affect traits under selection, such as milk production, to a greater extent than traits not under long-term selection, such as reproductive performance (Sørensen et al., 2008). Different population breeding goals may therefore be one contributing factor to the inconsistencies among studies on the effect of recombination on different traits; greater natural selection pressure may have been traditionally placed on Irish dairy cows to survive within the seasonal calving production system operated in Ireland (Berry et al., 2013), which may have implied weaker selection pressure on milk production. Furthermore, Ireland traditionally did not operate its own national breeding scheme and therefore the germplasm used originated from many different sources, minimizing the potential for favorable epistatic loci combinations to become established (and therefore lost through continual crossbreeding).

In theory, with rotational crossbreeding between 2 breeds, $67 \%$ of the $\mathrm{F}_{1}$ heterosis will be expressed ( $\mathrm{S} \phi-$ rensen et al., 2008; Buckley et al., 2014). Heterosis for 2 -way rotational crosses in the present study exceeded theoretical expectations, where $\mathrm{HO} \times \mathrm{JE}$ rotational 
crosses expressed $70 \%$ and $100 \%$ of the heterosis observed in the $\mathrm{HO} \times \mathrm{JE} \mathrm{F}_{1}$ for milk solids and calving interval, respectively.

\section{Economic Implications of Crossbreeding}

The ideal cow for future milk production in Ireland has been characterized as a robust, healthy, efficient, fertile, easy-care cow that produces a large quantity of high-value milk solids and remains resilient to external perturbations (Berry, 2015). It is essential to incorporate all traits of interest into breeding indices to breed a fit-for-purpose cow suitable for a given production system. The breeding strategy in New Zealand demonstrates the best example of large-scale crossbreeding with the Jersey breed, where Holstein-Friesian $\times$ Jersey crossbred cows account for $42.6 \%$ of the national dairy herd (LIC, 2015). The appropriateness of Jersey crossbreeding in intensive grazing systems is substantiated by the results from the present study and elsewhere (Lopez-Villalobos et al., 2000a; Prendiville et al., 2009, 2011; Buckley et al., 2014) owing to high productivity of milk solids complementing the milk payment system, superior fertility performance, improved longevity, and consequently, an expected increase in overall farm profit.

The introduction of a multi-component milk payment system that rewards milk solids production and penalizes milk volume in many countries (Shalloo et al., 2007) has initiated a growing interest in crossbreeding. Based on the likely future milk pricing, as described by Kelleher et al. (2015a), where a kilogram of milk, fat, and protein is worth $-€ 0.09$, €1.04, and €6.64 profit, respectively, all $\mathrm{F}_{1}$ crossbred cows in the present study generated more milk profit than the parental breed average (€67.12, €19.47, and €5.34 per lactation for Holstein $\times$ Jersey, Friesian $\times$ Jersey, and Holstein $\times$ Friesian $F_{1}$ cows, respectively). Similar trends were observed in New Zealand where Holstein-Friesian $\times$ Jersey cows produced $378 \mathrm{~kg}$ more milk and $28.7 \mathrm{~kg}$ more milk solids compared with the parental average (LIC, 2015), corresponding to $€ 79$ milk profit based on future milk pricing for Ireland (Kelleher et al., 2015a).

Based on the economic value of -€12.43 per day for calving interval in the Irish national breeding objectives (ICBF, 2014), the shorter calving interval in the present study was valued at $€ 94.47, € 115.60$, and $€ 68.37$ extra profit per lactation for Holstein $\times$ Jersey, Friesian $\times$ Jersey, and Holstein $\times$ Friesian $\mathrm{F}_{1}$ cows, respectively, compared with the parental breed average. Superior performance was also evident for age at first calving in the present study and, although no economic value is available for age at first calving in Ireland, this is also likely to contribute to overall profitability.
The economic benefits from superior milk production and reproductive performance in the present study equate to an additional $€ 162$, €135, and $€ 74$ profit per lactation for Holstein $\times$ Jersey, Friesian $\times$ Jersey, and Holstein $\times$ Friesian crossbred cows, respectively, relative to the parental breed average. This is consistent with previous economic analyses that attributed greater profitability to greater lifetime milk production, increased longevity, and lower replacement rates in crossbreds relative to their purebred contemporaries (Lopez-Villalobos et al., 2000a,b; Prendiville et al., 2011). Kelleher et al. (2015b) reported an additional $€ 472$ profit for Holstein $\times$ Jersey $F_{1}$ cows over their lifetime relative to the average of their purebred contemporaries.

Although not considered in the present study, crossbreeding has also been documented to contribute to superior health (Begley et al., 2009), feed efficiency (Grainger and Goddard, 2004; Prendiville et al., 2009), and longevity (Lopez-Villalobos et al., 2000a) in dairy cows. Because of improved milk composition, fertility, health, feed efficiency, and longevity observed in crossbred cows, an improvement in overall farm profitability is expected.

\section{CONCLUSIONS}

The findings from the present study corroborate previous conclusions from small-scale controlled experiments and illustrate the superior biological performance of crossbred cows relative to the average of parental breeds within seasonal-calving, grass-based commercial dairy herds. Moreover, the results indicate that the widespread adoption of crossbreeding offers the Irish dairy industry the opportunity to capitalize on heterosis for traits of economic importance and may result in a considerable improvement in profit. Consequently, to fully exploit crossbreeding and maximize attainable heterosis, high-genetic-merit bulls from complementary pure breeds must be available to dairy farmers.

\section{ACKNOWLEDGMENTS}

The authors acknowledge the financial support of the Irish Dairy Levy.

\section{REFERENCES}

Ahlborn-Breier, G., and W. D. Hohenboken. 1991. Additive and nonadditive genetic effects on milk production in dairy cattle: Evidence for major individual heterosis. J. Dairy Sci. 74:592-602.

Akbas, Y., S. Brotherstone, and W. G. Hill. 1993. Animal model estimation of non-additive genetic parameters in dairy cattle, and their effect on heritability estimation and breeding value prediction. J. Anim. Breed. Genet. 110:105-113. 
Baumont, R., E. Lewis, L. Delaby, S. Prache, and B. Horan. 2014. Sustainable intensification of grass-based ruminant production. Pages 521-532 in Grassl. Sci. Eur. Vol. 19. IBERS, Aberystwyth University, Aberystwyth, Wales.

Begley, N., F. Buckley, K. M. Pierce, A. G. Fahey, and B. A. Mallard. 2009. Differences in udder health and immune response traits of Holstein-Friesians, Norwegian Reds, and their crosses in second lactation. J. Dairy Sci. 92:749-757.

Berry, D. P. 2015. Breeding the dairy cow of the future: What do we need? Anim. Prod. Sci. 55:823-837.

Berry, D. P., J. F. Kearney, K. Twomey, and R. D. Evans. 2013. Genetics of reproductive performance in seasonal calving dairy cattle production systems. Ir. J. Agric. Food Res. 52:1-16.

Berry, D. P., E. Wall, and J. E. Pryce. 2014. Genetics and genomics of reproductive performance in dairy and beef cattle. Animal $8: 105-121$

Brotherstone, S., and W. G. Hill. 1994. Estimation of non-additive genetic parameters for lactations 1 to 5 and for survival in HolsteinFriesian dairy cattle. Livest. Prod. Sci. 40:115-122.

Buckley, F., B. Horan, N. Lopez-Villalobos, and P. Dillon. 2007. Milk production efficiency of varying dairy cow genotypes under grazing conditions. Pages 74-83 in Proc. Australasian Dairy Science Symposium, Melbourne. National Dairy Alliance, Australia.

Buckley, F., N. Lopez-Villalobos, and B. J. Heins. 2014. Crossbreeding: Implications for dairy cow fertility and survival. Animal 8:122-133.

Cassady, J. P., L. D. Young, and K. A. Leymaster. 2002. Heterosis and recombination effects on pig reproductive traits. J. Anim. Sci. 80:2303-2315.

Cassell, B. 2007. Mechanisms of inbreeding depression and heterosis for profitable dairying. Pages 1-6 in Proc. 4th Biennial W. E. Petersen Symposium, University of Minnesota, St. Paul. University of Minnesota Press, St. Paul.

Coleman, J., K. M. Pierce, D. P. Berry, A. Brennan, and B. Horan. 2010. Increasing milk solids production across lactation through genetic selection and intensive pasture-based feed system. J. Dairy Sci. 93:4302-4317.

Dechow, C. D., G. W. Rogers, J. B. Cooper, M. I. Phelps, and A. L. Mosholder. 2007. Milk, fat, protein, somatic cell score, and days open among Holstein, Brown Swiss, and their crosses. J. Dairy Sci. 90:3542-3549.

Department of Agriculture. 2014. AIM Bovine Statistics Annual Report. Accessed Jun. 10, 2015. http:// ww w.agriculture.gov.ie/media/migration/ animalhealthwelfare/animalidentificationandmovement/ c a t t l e m o v e m e n t m o n i t or i n g s y t e m / AIMBovineStatisticsReport2014050615.pdf.

Dezetter, C., H. Leclerc, S. Mattalia, A. Barbat, D. Boichard, and V. Ducrocq. 2015. Inbreeding and crossbreeding parameters for production and fertility traits in Holstein, Montbéliarde, and Normande cows. J. Dairy Sci. 98:4904-4913.

Dillon, P., D. Berry, R. Evans, F. Buckley, and B. Horan. 2006. Consequences of genetic selection for increased milk production in European seasonal pasture based systems of milk production. Livest. Sci. 99:141-158.

Dillon, P., J. R. Roche, L. Shalloo, and B. Horan. 2005. Optimising financial returns from grazing in temperate pastures. Pages 131147 in Proc. Satellite Workshop XXth Int. Grassl. Congr., Cork, Ireland. Wageningen Acad. Publ., Wageningen, the Netherlands.

Falconer, D. S., T. F. Mackay, and R. Frankham. 1996. Introduction to Quantitative Genetics. 4th ed. Trends in Genetics. Pearson Education Ltd., Harlow, UK.

Gilmour, A. R., B. R. Cullis, S. J. Welham, and R. Thompson. 2011. ASREML Reference Manual. VSN International Ltd., Hemel Hempstead, UK.

Grainger, C., and M. E. Goddard. 2004. A review of the effects of dairy breed on feed conversion efficiency - An opportunity lost? Pages 77-80 in Proc. 25th Biennial Conf. Aust. Soc. Anim. Prod., University of Melbourne, Victoria, Australia. CSIRO, Victoria, Australia.
ICBF. 2014. Understanding the Economic Breeding Index (EBI). Accessed Dec. 9, 2014. http://www.teagasc.ie/dairy/breeding/docs/ Understanding_EBI_PTA_BV_Spring_2014.pdf.

Jeangros, B., and P. Thomet. 2004. Multi-functionality of grassland systems in Switzerland. Pages 11-23 in Grassland Science in Europe. Vol. 9. VDF Hochschulverlag AG an der ETH Zurich, Zürich, Switzerland.

Kelleher, M. M., P. R. Amer, L. Shalloo, R. D. Evans, T. J. Byrne, F. Buckley, and D. P. Berry. 2015a. Development of an index to rank dairy females on expected lifetime profit. J. Dairy Sci. 98:4225-4239.

Kelleher, M. M., P. R. Amer, L. Shalloo, R. D. Evans, T. J. Byrne, F. Buckley, and D. P. Berry. 2015b. A novel index to rank dairy females on expected lifetime profit. Page 63 in Agricultural Research Forum, Tullamore, Ireland.

Kennedy, J., P. Dillon, L. Delaby, P. Faverdin, G. Stakelum, and M. Rath. 2003. Effect of genetic merit and concentrate supplementation on grass intake and milk production with Holstein-Friesian Dairy cows. J. Dairy Sci. 86:610-621.

LIC. 2015. New Zealand Dairy Statistics 2013-14. Accessed Oct. 15 , 2015. http://www.lic.co.nz/user/file/DAIRY\%20STATISTICS\%20 2013-2014-WEB_June2015.pdf.

Lopez-Villalobos, N. 1998. Effect of crossbreeding and selection on the productivity and profitability of the New Zealand dairy industry. PhD Thesis. Animal Science, Massey University, New Zealand.

Lopez-Villalobos, N., and D. Garrick. 2002. Economic heterosis and breed complementarity for dairy cattle in New Zealand. Pages 0137 in Proc. 7th World Congress on Genetics Applied to Livestock Production. INRA, France.

Lopez-Villalobos, N., D. J. Garrick, H. T. Blair, and C. W. Holmes. 2000a. Possible Effects of 25 years of selection and crossbreeding on the genetic merit and productivity of New Zealand dairy cattle. J. Dairy Sci. 83:154-163.

Lopez-Villalobos, N., D. J. Garrick, C. W. Holmes, H. T. Blair, and R. J. Spelman. 2000b. Effects of selection and crossbreeding strategies on industry profit in the New Zealand dairy industry. J. Dairy Sci. 83:164-172.

Lopez-Villalobos, N., D. J. Garrick, C. W. Holmes, H. T. Blair, and R. J. Spelman. 2000c. Profitabilities of some mating systems for dairy herds in New Zealand. J. Dairy Sci. 83:144-153.

Lyons, S., K. Mayor, and R. S. Tol. 2008. Environmental accounts for the Republic of Ireland: 1990-2005. J. Stat. Social Inq. Soc. Ireland 37:190-216.

Macdonald, K. A., J. W. Penno, J. A. S. Lancaster, and J. R. Roche. 2008. Effect of stocking rate on pasture production, milk production, and reproduction of dairy cows in pasture-based systems. J. Dairy Sci. 91:2151-2163.

McCarthy, B., K. M. Pierce, L. Delaby, A. Brennan, C. Fleming, and B. Horan. 2013. The effect of stocking rate and calving date on grass production, utilization and nutritive value of the sward during the grazing season. Grass Forage Sci. 68:364-377.

McCarthy, J., L. Delaby, D. Hennessy, B. McCarthy, W. Ryan, K. M. Pierce, A. Brennan, and B. Horan. 2015. The effect of stocking rate on soil solution nitrate concentrations beneath a free-draining dairy production system in Ireland. J. Dairy Sci. 98:4211-4224.

McCarthy, S., B. Horan, P. Dillon, P. O'Connor, M. Rath, and L. Shalloo. 2007. Economic comparison of divergent strains of Holstein-Friesian cows in various pasture-based production systems. J. Dairy Sci. 90:1493-1505.

O'Mara, F. 2008. Country Pasture/Forage Resource Profile-Ireland Page. Accessed Feb. 22, 2014. http://www.fao.org/ag/AGP/ AGPC/doc/counprof/Ireland/Ireland.htm.

Penasa, M., N. Lopez-Villalobos, R. D. Evans, A. R. Cromie, R. Dal Zotto, and M. Cassandro. 2010. Crossbreeding effects on milk yield traits and calving interval in spring-calving dairy cows. J. Anim. Breed. Genet. 127:300-307.

Peyraud, J., A. Van den Pol-Van Dasselaar, P. Dillon, and L. Delaby. 2010. Producing milk from grazing to reconcile economic and environmental performances. Grassl. Sci. Eur. 15:865-879.

Prendiville, R., K. M. Pierce, and F. Buckley. 2009. An evaluation of production efficiencies among lactating Holstein-Friesian, Jer- 
sey, and Jersey $\times$ Holstein-Friesian cows at pasture. J. Dairy Sci. 92:6176-6185.

Prendiville, R., K. M. Pierce, L. Delaby, and F. Buckley. 2011. Animal performance and production efficiencies of Holstein-Friesian, Jersey and Jersey $\times$ Holstein-Friesian cows throughout lactation. Livest. Sci. 138:25-33.

Pretty, J. N. 1997. The sustainable intensification of agriculture. Nat. Resour. Forum 21:247-256.

Ramsbottom, G., A. R. Cromie, B. Horan, and D. P. Berry. 2012. Relationship between dairy cow genetic merit and profit on commercial spring calving dairy farms. Animal 6:1031-1039.

Ramsbottom, G., B. Horan, D. P. Berry, and J. R. Roche. 2015. Factors associated with the financial performance of spring-calving, pasture-based dairy farms. J. Dairy Sci. 98:3526-3540.

Roche, J. R., L. R. Turner, J. M. Lee, D. C. Edmeades, D. J. Donaghy, K. A. Macdonald, J. W. Penno, and D. P. Berry. 2009. Weather, herbage quality and milk production in pastoral systems. 2. Temporal patterns and intra-relationships in herbage quality and mineral concentration parameters. Anim. Prod. Sci. 49:200-210.

Shalloo, L., S. O'Donnell, and B. Horan. 2007. Profitable dairying in an increased EU milk quota scenario. Pages 20-44 in Proc. National Dairy Conference: Exploiting the Freedom to Milk. Teagasc, Ireland.

Soder, K. J., and C. A. Rotz. 2001. Economic and environmental impact of four levels of concentrate supplementation in grazing dairy herds. J. Dairy Sci. 84:2560-2572.

Sørensen, M. K., E. Norberg, J. Pedersen, and L. G. Christensen. 2008. Invited review: Crossbreeding in dairy cattle: A Danish perspective. J. Dairy Sci. 91:4116-4128.

Spelman, R. J., B. J. Hayes, and D. P. Berry. 2013. Use of molecular technologies for the advancement of animal breeding: Genomic se- lection in dairy cattle populations in Australia, Ireland and New Zealand. Anim. Prod. Sci. 53:869-875.

Steinfeld, H. and J. Maki-Hokkonen. 1995. A Classification of Livestock Production Systems. FAO Corporate Document Repository. Food and Agriculture Organization of the United Nations, Rome, Italy.

Swan, A. A., and B. P. Kinghorn. 1992. Evaluation and exploitation of crossbreeding in dairy cattle. J. Dairy Sci. 75:624-639.

Taube, F., M. Gierus, A. Hermann, R. Loges, and P. Schönbach. 2014 Grassland and globalization - Challenges for north-west European grass and forage research. Grass Forage Sci. 69:2-16.

Vance, E. R., C. P. Ferris, C. T. Elliott, H. M. Hartley, and D. J. Kilpatrick. 2013. Comparison of the performance of Holstein-Friesian and Jersey $\times$ Holstein-Friesian crossbred dairy cows within three contrasting grassland-based systems of milk production. Livest. Sci. 151:66-79.

Vance, E. R., C. P. Ferris, C. T. Elliott, S. A. McGettrick, and D. J. Kilpatrick. 2012. Food intake, milk production, and tissue changes of Holstein-Friesian and Jersey $\times$ Holstein-Friesian dairy cows within a medium-input grazing system and a high-input total confinement system. J. Dairy Sci. 95:1527-1544.

VanRaden, P. M., and A. H. Sanders. 2003. Economic merit of crossbred and purebred US dairy cattle. J. Dairy Sci. 86:1036-1044.

Wall, E., S. Brotherstone, J. Kearney, J. Woolliams, and M. Coffey. 2005. Impact of nonadditive genetic effects in the estimation of breeding values for fertility and correlated traits. J. Dairy Sci. $88: 376-385$.

Washburn, S. P., and K. A. E. Mullen. 2014. Invited review: Genetic considerations for various pasture-based dairy systems. J. Dairy Sci. 97:5923-5938. 